\title{
Hayvan Haklarına Yönelik Temel Görüşler ve Yanılgıları \\ Öz
}

$\mathrm{Bu}$ makalede hayvan hakları savunucularının görüşlerini ele alıp birbirleri ile farklarını ortaya koymakla birlikte onların insan-merkezciliğe yönelttikleri temel eleştirilerine de değinilecektir. Burada hayvan hakları savunucularının insanmerkezci düşünce biçimine getirdiği en temel eleştiri etiğin sınırlarının genişletilmesi gerekliliğidir. Hayvan hakları savunucularından bazıları yalnızca duyarlı hayvanları bu sinıra dahil ederken ki bunlardan en önemlisi Peter Singer'dır başka bazıları ise öznel bir yaşama sahip olmayı, yani kendi dünyasına sahip olmayı bu sınıra dahil eder ki bu düşünürlerden en önemlisi de Tom Regan'dır. Ancak burada hayvan hakları savunucularının insan-merkezci düşünce biçimine getirdikleri eleştirilerin aynısını onlara da getirmek mümkün gözükmektedir. $\mathrm{Bu}$ bakımdan bu düşünürlerin eleştirdikleri düşünce biçiminden kurtulamadıklarını göstermek bu makalenin temel amacı olacaktır.

\section{Anahtar Kelimeler}

İnsan-Merkezcilik, Etik, Hayvan Hakları, Peter Singer, Tom Regan.

\section{The Basic Approaches to Animal Rights and Their Misconceptions}

\begin{abstract}
This article deals with the views of animal rights advocates and reveals their differences with each other, as well as the basic criticisms they have directed towards anthropocentrism. Here the most basic criticism of animal rights advocates towards anthropocentrism is the necessity of expanding the boundaries of ethics. Some of the advocates of animal rights include only sentient animals in this class, the most important of which is Peter Singer, while others include having a subjective life, that is to say having own world, which is the most important of these thinkers, Tom Regan. However, it seems possible to bring to them the same criticisms that animal rights advocates have made to anthropocentrism. From this point of view, it will be the main objective of this article to show that these thinkers can not get rid of their criticized way of thinking.
\end{abstract}

\section{Keywords}

Anthropocentrism, Ethics, Animal Rights, Peter Singer, Tom Regan. 


\section{Giriş}

Düşünce tarihine baktığımızda insanın kendini ve doğayı anlamlandırmasının insan-merkezli bir şekilde gerçekleştiğini görmekteyiz. "İnsan-merkezcilik sınırlı bakış açısına sahip insana dünyayı anlayabilmeleri için belirli bir düzen ve yapı sunar" (Steiner 2005: 1). Bu bakımdan şeylerin sıra ve düzenini insanın kendi bakış açısına göre ve kendisini merkeze alarak açıklaması olarak anlaşılan insan-merkezcilik dinsel, kozmolojik ve felsefesi açıdan ele alınabilmektedir. "Encyclopedia of Environmental Ethics and Philosophy" kitabının içinde yer alan "Anthropocentrism" başlıklı bölümünde (2009) Ben A. Minteer'in felsefe tarihini ele alarak yapmış olduğu analize göre, felsefi açıdan insan-merkezli düşünce etik, ontolojik ve epistemolojik bağlamda ele alınabilir. Etik bir görüş olarak insan-merkezcilik yalnızca insan varlığının içsel bir değere sahip olduğu, diğer tüm varlıkların ve şeylerin sadece araçsal değere sahip olduğu iddiasına dayanır. Ontolojik bakışla insan-merkezcilik, bazen Aristotelesçi veya Thomasçı olarak tanımlanan, insanların evrenin merkezinde veya yaratılışın sonunda olduğuna dair görüşü temsil eder. Son olarak epistemolojik bakışla insan-merkezciliğin ise totolojik bir çıkarım olduğu düşünülür. Burada tüm insani değerler, insan-merkezci olmayanlarca doğaya atfedilen içsel değer de, insan tarafından ortaya atılan değerlerdir şeklinde bir düşünüş vardır (Minteer 2009: 58-59). Bu bakımdan her bir insan-merkezci bakış açısı, insanın değerli ve merkezde olduğunu var sayarak diğer canlıları insan açısından değerlendirir.

İnsan-merkezcilik açısından baktığımızda insanlar doğrudan ahlaki statüye sahiplerdir, çünkü “insanlığın kendisinin sonu, diğer şeylerin, yani bireysel varlıklar ve eko sistemin de sonu anlamına gelmektedir" (Goralnik ve Nilson 2012: 145). Buradaki son diğer canlıların varlıklarının sona ermesi anlamında bir son değildir. Buradaki sondan daha çok dünyayı anlamlandıran, değerlendiren ve değerli kılan varlığın sonu ile anlamını ve değerini kaybeden bir doğa ve dünya anlaşılır. Bu anlayışın kaynağı yalnızca insanların ahlaki değerleri tanıma ve formüle etme bilincine sahip olduğu düşüncesidir. Bu bakımdan ortaya atılan tüm etik öğretiler insan ürünü olduğundan, tüm etiklerin insan-merkezci olması gerektiği düşüncesi doğar. Bu durum, kurulan tüm etik sistemlerin merkezine insanın yerleşmesini sağlar. Bu bakımdan Batı felsefesinin insanmerkezci olduğunu söylemek yanlış sayılmaz: "Dört yüzyıldır Batı felsefesi ve teolojisi ağırlıklı olarak insan-merkezlidir” (Rolston 2012: 1-2). Ancak kabul etmeliyiz ki “insan varlığının objektifi (görüş alanı) sınırlı bir bakış açısına sahiptir ve bizler hala dünyada bulduğumuz değerleri o bakış açısından seçeriz" (Goralnik ve Nilson 2012: 145). Buradaki düşünce bizim bilişsel yetimizi ve etik yaklaşımımızı ontolojik insanmerkezcilik bağlamında belirlediğine işaret etmektedir. Ancak genel olarak dünyaya olan sınırlı bakışımız göz ardı edilerek "insan-merkezciliğin belirlenmesinden anlaşılan ise içsel değerin tek sahipleri olarak insanların, ahlaksal açıdan insan merkezciliğidir" (Goralnik ve Nilson 2012: 145). Bu bakımdan burada ortaya ahlaki fail olma ile ahlaki ilgiye layık olma özdeşliği sorunu çıkmaktadır.

Geleneksel etik kuramların ortak özelliği insanı yalnızca ahlaki fail olarak değil, aynı zamanda ahlaki davranışlarımızın tek nesnesi olarak düşünmeleridir. Bu bakımdan genel olarak ahlaki fail olma ile hak sahibi olma, yani ahlaki davranışlarımızın konusu olma eşit düşünülmüştür. Böylece diğer canlılar ahlaki fail olma özelliği gösteremediklerinden dolayı hak sahibi de olamamışlardır. Felsefe tarihine baktığımız 
zaman Aristoteles’ten Aquinas’a, Descartes’ten Kant ${ }^{1}$ 'a kadar filozoflar diğer canlıları hak sahibi olarak görmemişlerdir. Derrida'ya göre ${ }^{2}$ ise bu filozofların yanına Heidegger'den Levinas'a kadar gelen süreçteki filozoflar da eklenmelidir. Felsefe tarihine baktığımızda örneğin, Aristoteles "Politika" kitabında doğanın insana özel yapıldığından bahseder ${ }^{3}$. Aquinas diğer canlılara yapılan davranışları insana zarar verdiği takdirde yanlış olarak değerlendirir ${ }^{4}$. Ancak Descartes'a gelindiğinde hayvanlar

1 Kant'a göre, "varoluşları bizim istememize değil de, doğaya dayanan varlıkların, akıl sahibi olmayan varlıklar olunca yine de araç olarak ancak göreli bir değeri vardır" (Kant 2002: 45). Kant intihar üzerine yaptığı yorumda insanın bazı koşullarda canlarını feda edebileceklerini söylerken bu durumlar dışında intiharı olumsuzlar. İntiharı olumsuzlamasının sebebi ise insanı kutsal bir varlık olarak görmesidir. Aynı zamanda burada Kant diğer canlıların da insana tabi olduğunu dile getirerek Aristoteles ve Aquinas ile aynı konumu paylaşır: "Kendi kişisinde insan çiğneyemeyeceği bir şeye sahiptir; bu insana emanet edilen kutsal bir şeydir. Diğer her şey insana tabidir... İnsan hayatın kendisine emanet edildiğini görür ve hisseder. Ve eğer hayatı kendi aleyhine çevirirse (intihar), kendisine bahşedilen bu kutsi güveni sarsmak düşüncesinden geri adım atması gerekir. İnsanın başından savabileceği/atabileceği şey ise bir nesne olmalıdır (thing). Hayvanlar burada nesne olarak düşünülmüştür ancak insan nesne değildir, fakat yine de insan kendi hayatını başından savarsa kendisini bir hayvan değeriyle bir tutmuş olur" (Kant 1997: 147). Bu bakımdan Kant diğer canlıları insana tabi olarak düşünür ve onların yalnızca araçsal değeri vardır diyerek onları kullanmamıza olanak tanır: "İnsan hayvanları hızlı bir şekilde (acısız) öldürme ve onların kapasitelerini aşmayan, yani onlara uygun işlerde onları çalıştırma yetkisine sahiptir” (Kant 1991: 238).

2 Derrida logos merkezli düşünüş biçiminin aynı zamanda insan-merkezci düşünüş biçimi olarak hayvana ilişkin bir tez olduğunu öne sürer. Çünkü logosantrizm'de veya insan merkezcilikte hayvan logostan veya insana ait özelliklerden mahrum bir varlık olarak öne sürülür. Derrida’ya göre, bu tez “Aristoteles’ten Heidegger’e, Descartes’tan Kant'a, Levinas ve Lacan'a kadar muhafaza edilen bir tez, pozisyon ya da varsayımdır” (Derrida 2002: 395396).

3 “... Bir kez bitkilerin hayvanlar için, ikinci olarak da tüm öteki hayvanların insanlar için var olduğuna inanmamız gerekir - evcil hayvanlar, insanın onlardan sağlayabileceği besinin yanı sıra, kullanabileceği gibi kullanması için, vahşî hayvanların da hepsi değilse bile çoğu, yiyecek olarak işe yarar ve başka bakımlardan kullanılır; kendilerinden giyecekler ve araçlar yapılabilir. Doğanın amaçsız bir şey yaratmadığına, boşu boşuna bir şey yapmadığına inanmakta haklıysak doğa tüm şeyleri özel olarak insan için yapmış olmalıdır” (Aristoteles 1993: 1. kitap 8. bölüm 1256b sf. 18-19).

4 Tüm hayvanlar doğal olarak insana tabidir. Bu, üç yoldan ispatlanabilir. Birincisi, doğanın düzeninden; çünkü şeylerin oluşmasında kusurlu olandan kusursuzluğa doğru belirli bir düzenini algıladığımız için (bu nedenle madde form uğruna ve kusurlu olan kusursuz olan uğruna vardır), aynı zamanda orada doğal şeylerin kullanımındaki düzen de vardır. Böylece kusurlu olanlar, kusursuz olanın kullanımı içindir; bitkiler kendi beslenmeleri için yeryüzünü kullanır, hayvanlar bitkiyi kullanır ve insan hem bitkilerden hem de hayvanlardan faydalanır. $\mathrm{Bu}$ nedenle, doğanın düzenine uygun olarak, insan hayvanlar üzerinde egemendir. Dolayısıyla filozofların dediği gibi vahşi hayvanların avlanması adil ve doğaldır, çünkü insan doğal bir hakka sahiptir. İkinci olarak, ilahi kudret'in düzeni tarafindan üstün olanın altta olanı yönetmesi ispat olarak gösterilebilir. Tanrı'nın suretinden yapıldığından dolayı insan diğer hayvanların üzerinde olduğu için onları yönetme hakkına sahiptir. Üçüncü olarak insan ve diğer canlıların özelliği sunulur. Diğer canlılarda belirli eylemler ile ilgili olarak, doğal içgüdüden pay alan belirli bir sağduyuyu görürüz; oysa insan, pratik konularda evrensel bir sağduyuya sahiptir. Şimdi her ne pay alırsa pay alan her zaman esas ve evrensel olana tabidir. 
ve diğer canlılar ruhsuz birer makine olarak görülmeye başlanmıştır. Descartes iradeden hiçbir şekilde pay almayan hareketlerin mekanik hareketler olduğunu söyler ve ona göre, hayvanların iradeye dayalı hareketleri olmadığından onların hareketleri mekaniktir. Hayvanların birer makine olarak tasarlanması demek onların acı çekmediğini var saymaktır. ${ }^{5} \mathrm{Bu}$ bakımdan Descartes'in bu tezi hayvanlara acımasız davranışın kırılma noktasıdır. Descartes'ın bu tezinin yanı sıra ortaya çıkan kapitalist ekonomi biçimi ve doğaya egemen olma düşüncesi artık insan ile diğer canlılar arasındaki ilişki biçiminde de değişiklik yaratmıştır. Diğer canlılar zamanla insan için birer "şey" haline indirgenmiştir. İnsanlar kendi amaçlarına ulaşmak ve daha fazla üretmek/tüketmek için diğer canlılara karşı giderek acımasızlaşmıştır. Bu acımasız tutum özellikle üretim biçimlerine yansımaktadır. İnsanlar daha fazla gıda elde etmek için hayvanlara zulüm etmekte onlardan sanayi malı olarak seri bir şekilde "ürün" elde etmektedirler. Bunların sonucunda günümüz dünyasına baktığımızda en büyük problemler arasında iklim değişikliği, canlı türlerinin yok olması ve diğer canlılara acımasız davranmanın yer aldığını görmekteyiz.

\section{Temel Hayvan Hakları Görüşleri}

Son yüzyıl içerisinde insan-merkezci düşünce biçimine çok büyük eleştiriler getirilmiştir. Bu eleştiriler özellikle hayvanların da etik davranışlarımızın kapsamı içerisine dahil edilmesi gerektiğini vurgular. Bu düşünceleri ve eleştirileri daha iyi anlayabilmek için belli başlı bazı düşünürlerin görüşlerine değinmek gerekmektedir. Bunların başında her ne kadar hayvan hakları savunucusu olmasa da bu düşüncenin önünü açması bakımından J. Bentham gelmektedir. Ardından genellikle biyolog olarak bilinen, fakat hayvanların birer makine olduğu görüşüne karşı eleştiriler getiren Jakob von Uexküll'a değinilecektir. Bu iki temel düşünürün ardından hayvan hakları konusunda en önemli iki isim Peter Singer ve Tom Regan'ın görüşlerine değinilecektir. Makalenin sonunda ise her ne kadar hayvanlara yönelik bu düşünceler olumlu bir gelişme olarak görülse de aslında bu düşüncelerin insan-merkezci düşünce biçiminden kurtulamadığı gösterilmeye çalışılacaktır. Bu bakımdan hayvan hakları veya hayvan

$\mathrm{Bu}$ nedenle diğer hayvanların insana boyun eğmesinin doğal olduğu kanıtlanmıştır (Aquinas 1920-1925: 1, question 96, Article 1, Answer).

5 Descartes hayvanların hissi özelliklere sahip olmadığını tepkisel harekete sahip olduklarını şu şekilde belirtir: "İnsanlar düşerken başlarını korumak için ellerini uzattıklarında onlara bu hareketi yapmalarını söyleyen herhangi bir sebep yoktur; bu sadece yaklaşan düşüşün beyne ulaşması ve bir makinede üretilebileceği gibi hiçbir zihinsel istem olmaksızın bile hareketi üretmek için gerekli şekilde sinirleri hayvan ruhuna gönderme işlemidir. Ve kendi terübemiz bunun doğru olduğunu bize bildirdiğinden, neden bir kurtun gövdesinden bir koyunun gözlerine yansıyan ışı̆̆ın, koyundaki 1şık hareketlerini eşit derecede alevlendirebileceği bizi şaşırtmalı?" (Descartes 1991: II: 161).

Descartes, Mersenne'a yazdığı bir mektupta bu durumu şöyle açıklar: "Ruha atıfta bulunmadan acı hissini açıklayamıyorum. Benim anlayışıma göre acı (pain) yalnızca anlayışta (understanding) var olur. Bizdeki bu hislere eşlik eden tüm dişsal hareketler hayvanlarda içsel hislere eşlik etmeden oluşan hareketlerdir ve tam anlamıyla bu acı değildir" (Descartes 1991: 
refahı gibi fikirlerin etik değerlendirme açısından yetersiz oldukları ortaya konmaya çalışılacaktır.

Etik hakkında çağdaş yazılarda bir varlığın "duyarlı" (sentient) olduğunu söylemek genellikle o varlığın acı veya hazzın bilincine sahip olduğu anlamına gelmektedir. Bununla birlikte, etimolojik açıdan "duyarlı" terimi acı ve hazzın bilincinden ziyade, daha geniş anlamda bir şeylerin bilincinde olmayı ifade eder ve bu kullanım çağdaş duyarlılık etiğinin en önemli savunucularının fikirlerinde görülür. Peter Singer bu terimi acı ve hazzın bilincinde olma şeklinde yorumlarken, Joel Feinberg ve Tom Regan hayvanların ahlaki ehliyeti konusunda acının bilincinden ziyade, hayvanlar aleminde daha az yaygin olan "kapasiteye sahip olma" durumuna bakarlar. John Rodman ise duyarlılık terimini bir "izm” (sentientism) şeklinde ilk kullanan kişidir. Ona göre bu etik, bilinçli varlıkların ahlaki ehliyete sahip olması ile sınırlıdır (Varner 2001: 192).

Hayvan hakları veya hayvan refahı gibi etik düşüncelerin gelişimine baktığımızda ise ilk olarak günümüzden yaklaşık iki yüz yıl önce yaşamış olan faydacı filozof J. Bentham'a değinmek gerekmektedir. Peter Singer'a göre, Bentham'ın ortaya attığı kuram aslında hayvan haklarına yönelik ilk olumlu gelişmedir. Bentham kuramında, krizin temel sebebinin Batı metafiziği boyunca süregelen insanın akıllı bir varlık olmasından dolayı elde ettiği üstünlük olduğunu belirtir. Bu bağlamda haklar veya ahlak konusundan bahsedeceksek eğer, temel sorunun diğer canlıların akıllı olup olmaması ya da konuşabiliyor olup olmamasında aranmaması gerektiğini, asıl sorulması gereken sorunun bu canlıların acı çekebiliyor olup olmadıklarını sormak olduğunu belirtir. Benthama’a göre:

Gün gelir insan dışındaki canlılar bazı haklar elde edebilir, o zaman bu haklar onlardan despot bir el dışında hiçbir şekilde geri alınamaz. Fransızlar derinin siyahlığının bir insanın kendisine eziyet edilmesinin bir nedeni olmadığını çoktan keşfettiler. Bir gün bacakların sayısı, derinin ne ile kaplandığı ya da kuyruk sokumu kemiğinin yok olması gibi şeylerin duyarlı bir varlığı aynı kadere terk etmek için eşit derecede yeterli bir neden olmadığının kabul edilmesi gerekebilir. Başka nasıl aşılamaz sınır aşılabilir? Bu sınırı aşabilmek belki de, akıl veya konuşma yetisine mi bağlıdır? Fakat yetişkin bir at veya köpek her ne kadar sosyal olsalar da akla sahip olan bir günlük, bir haftalık veya bir aylık bebek ile karşılaştırılamaz. Fakat tersi durumu farz ettiğimizde ne yararı olurdu? Soru, onlar akıllı davranabilir mi ya da konuşabilir mi sorusu değil, temel soru onlar acı çekebilirler mi sorusudur (Akt. Singer 2002: 7).

Peter Singer, Bentham'ın bu teorisini olumlu bir gelişme olarak görse de hayvan hakları konusunda yetersiz bulur. Canl1-merkezci düşünür Albert Schweitzer ise Bentham'ın kendi etiği kapsamında hayvanlara yer verdiğini, fakat onun insanlar ile ilişkisinde büyük acımasızlığı önlemek için hayvanlara iyi davranılması gerektiğini savunduğunu belirtir. Bununla birlikte Bentham'ın faydacı görüşü hayvan hakları ve refahı konusunda ilk olumlu gelişme olarak değerlendirilebilir.

İkinci olarak biyolog Jacop Von Uexküll'ün Descartes'in hayvanların ruhsuz birer makine olduğu dolayısıyla acı çekmediğine dair görüşlerine getirdiği eleştiriler ve ortaya koyduğu yeni fikirler hayvan hakları için önemlidir. Uexküll "A Foray İnto The Worlds of Animals and Humans" (2010) kitabında hayvanların mekanik bir şekilde 
düşünülemeyeceğini ve her canlının kendisine has algısal dünyası olduğunu öne sürerek kendi teorisini yeni bir bilime giriş olarak düşünülmemesi gerektiğini, sadece bilinmeyen dünyaya bir yürüyüşü tanımlama çabası olarak tanımlar. Uexküll, insan dışındaki varlıkların bir makine olarak tanımlanmasına karşı olarak bizim aletlerimiz ve makinelerimizin, ürünler (trenler, arabalar, uçaklar, teleskop, vb.) üretmeye yaramaktan başka insan varlığına herhangi bir yardımı yoktur der. Bu şeylerin hayatımızı kolaylaştırdığı şüphesiz bir gerçektir. Ancak hayvanları makine olarak düşünmek onları da tamamen işe yarayacak eşya olarak düşünmek demektir. Hayvanları makine olarak görenler onları diğerleri gibi alet ya da araç olarak düşünürler. Bu bağlamda onlar için hayvanlar özne olmaktan uzak birer nesnedirler. Uexküll'e göre, duyu organlarımızın algılamaya motor organların da etki üretimine hizmet ettiğini düşünen birisi artık hayvanları da mekanik bir montaj olarak göremeyecektir. Bu insanlar aynı zamanda bizim gibi bir vücuda gelmiş ve organlardan oluşmuş öznelerin aynı zamanda bir makine operatörü gibi olduklarını keşfedeceklerdir. İşte bu keşif onları hayvanlara yönlendirecektir ve onların da kendi vücutlarının operatörleri olarak kendi algısal dünyaları ve bu dünyadaki etkilerini görebilecektir. Bu bağlamda artık bu kişiler diğer canlıları bir nesne olmaktan ziyade özne olarak düşüneceklerdir (Uexküll 2010: 41-42).

Uexküll'e göre bu kişiler, bir öznenin algıladığı her şeyin kendi algısal dünyasına (Merkwelt) ait olduğundan onun ürettiği her şey de kendi etki dünyasına (Wirkwelt) ait olduğunu keşfeder. Dolayısıyla kendi dünyasını algılayan ve kuran özne olarak hayvan kendi dünyası ile yani çevresi ile sınırlıdır. Bunun sonucunda hayvanların kendileri kadar çeşitli çevreler vardır. Uexküll yaşayan canlıların her birinin çevresini sabun köpügüne benzetir. $\mathrm{Bu}$ köpük her hayvanın çevresini temsil eder ve öznenin erişebileceği tüm özelliklerini içerir. Böyle bir köpüğün içine girer girmez öznenin önceki çevresi tamamen yeniden şekillendirilir. Bu bağlamda öznede yeni bağlantılar oluşturarak yeni bir algı dünyası oluşur ve böylece her köpükte yeni bir dünya oluşur. Uexküll’ün sabun köpüğ̈̈ metaforu aslında her canlının algısal dünyasının sınırını betimlemektedir. $\mathrm{Bu}$ şekilde düşündüğümüzde canlı çeşitliliği kadar köpük vardır diyebiliriz. Sonuç olarak Uexküll'e göre, canlıların her birinin kendi öznel dünyaları vardır ve bu dünyalar o canlıların kendi çevresiyle kurduğu algısal ilişki ile oluşur. $\mathrm{Bu}$ dünyaların hiç biri bir diğerine karşı üstün değildirler, çünkü her bir dünya öznel olduğundan dolayı onları üstünlük açısından karşılaştırmak mümkün değildir. Her bir canlının kendi algısal kapasitesi ve çevresi bağlamında oluşturduğu bu birbirinden farklı dünyalar bize insanın diğer canlılardan üstün olamayacağını söylemektedir (Uexküll 2010: 42-43).

Hayvan hakları ve refahı görüşleri içerisinde en etkili isimlerde birisi de Peter Singer'dır. Singer'ın "Practical Ethics" (2011) kitabına baktığımızda onun genel olarak faydacı düşünürler arasında yer aldığını söyleyebiliriz. Ancak onu diğer faydacı düşünürlerden ayıran yan Singer'ın sadece insanların değil, hissetme yetisi olan tüm canlıların mutluluklarını merkeze alan faydacı bir görüş ortaya atmasıdır. Bununla birlikte Singer kendi faydacılık görüşünün hedonistik değil, tercihe dayalı olduğunu söyler. O, tercihe dayalı faydacılığın evrensel etik görüşlerinden çıkarılmadığını iddia eder. Singer tercihe dayalı faydacılık kuramında tercihin evrenselleştirilmesinden ziyade, kişisel çıkara dayalı karar vermenin evrenselleştirilmesi ile tercihin ilk aşamasına ulaştığımızı söyler. Singer tercihe dayalı fayda etiğinde haz kavramının 
tercihleri tatmin etmesi durumunda, acı kavramının ise tercihleri tatmin edememesi durumunda ortaya çıkacağını düşünür (Singer 2011: 11-13).

Singer'ın tercihe dayalı faydacılık kuramı, menfaatlerin eşit şekilde dağıtılması ilkesi ile birlikte düşünülmelidir. Ancak buradaki eşitlik klasik eşitlik olan eşit muamele değil, eşit değerlendirme fikridir. Singer'a göre, "eşitliğin temel ilkesi eşit ya da aynı muameleyi gerektirmez, eşit değerlendirmeyi gerektirir" (Singer 2002: 3). Örneğin, eşitlik ilkesi bağlamında bir çocuğa atılan tokat ile bir ata atılan tokat aynı acı oranına sahip değildir. Ancak eşit değerlendirme ölçütü ile düşünürsek çocuğa vurulan tokadın daha büyük bir acıya yol açacağını görürüz. Singer burada eşit muamelenin yol açtığı soruna değinirken, yapılması gerekenin çıkarların eşit ölçüde göz önünde bulundurulması gerektiği olduğunu belirtir. $\mathrm{Bu}$ durumda Singer'a göre, ahlaksal yeterliliğe sahip bir kişi eylemde bulunurken eyleminin tüm acıya duyarlı varlıklar üzerinde etkisini düşünmesi gerekmektedir.

Singer bir kaya parçasının ya da bir taşın acı duyamayacağını belirtir ve bu yüzden bunların çıkarlarından söz edilemez der. Bu durumda bir canlının çıkar sahibi olabilmesi acı ve haz duyma yetisine bağlanmıştır. Singer sadece çıkar sahibi olabilen, yani haz ve acı duyabilen varlıkların ahlaki yönden ilgi görmeye ehliyetlerinin olabileceğini düşünür. Singer'ın bu iddialarına karşı bazı filozoflar 'bir varlığın hak sahibi olabilmesi için özerk veya bir topluluğun üyesi olması gerektiğini veya diğer canlıların haklarına saygı duyabilme yetisine veya bir adalet duygusuna sahip olması gerektiğini belirtirler" (Singer 2002: 8). Ancak bu iddiaların hayvan özgürlüğü ile ilgisi yoktur. Singer bu tür iddiaların türcülük veya 1rkçılık olduğunu düşünür: "Irkçıllar kendi çakarları ve başka bir ırkın üyelerinin çıkarları çatıştığında kendi ırklarına mensup olanların çıkarlarına daha fazla ağırlık vererek eşitlik ilkesini çiğnerler. Cinsiyet ayrımcıları kendi cinslerinden olanların çıkarlarını ön planda tutarak eşitlik ilkesini çiğnerler. Aynı şekilde, türcüler kendi türlerinin çıkarlarının diğer türlerin çıkarlarını ezmesine izin vermektedirler. Davranış tarzı her durumda aynıdır” (Singer 2002: 9).

Hayvan hakları konusunda düşünen bir diğer önemli düşünür olan Tom Regan ise Singer'ın faydacılık kuramını yetersiz bulur ve eleştirir. Ona göre:

1- "Başkalarına fayda sağlamak için masum bir canlıyı katletmek yanlıştır.

2- Faydacılık bunun neden yanlış olduğunu açıklayamaz durumdadır.

3- Dolayısıyla faydacilık yetersizdir" (Regan 2003: 85).

Regan'ın eleştirileri sadece faydacılık kuramına yönelik değildir, daha çok Kant eleştirisi üzerinden giderek kendi kuramını oluşturmaya çalışmıştır. "Animal Rights, Human Wrongs” (2003) kitabında Regan, Kant'ın kişi kavramına ${ }^{6}$ atfettiği anlama

6 Regan, Kant'ın ahlak yasasına göre eylemde bulunabilme özelliği olan akıl sahibi canlılara kişi dediğini belirtir. Bu bakımdan özerklik ile değerli olma ve dolayısıyla kişi olma arasında sıkı bir bağ vardır: "Demek ki özerklik insanın ve her akıl sahibi varlığın değerinin temelidir" (Kant, 2002: 53). Bu yüzden hayvanlar değerli değildir, çünkü özerk bir şekilde eyleyebilme kapasiteleri yoktur: "İnsanlar insan dişındaki diğer varlıklara karşı ahlaki ödeve sahip değildir; ve eğer bir kişi, insanlar dışındaki varlıklara karşı ahlaki olarak yükümlü olduğunu düşünüyorsa bunun nedeni bu kişinin refleksif kavramlarındaki karışıklıktır ve bu kişinin diğer canlılara karşı hissettiği ödevler aslında kendine karşı olan ödevleridir. Bu karışıklığı 


\section{$246 \quad$ KOYQl 2018/30}

baktığımızda her insanın kişi olmadığını görürüz der. Regan'a göre, yeni döllenmiş bir insan yumurtası ve kalıcı komada olan bir insan da insandır, fakat ikisi de Kant'ın kişiden kastettiği anlamda kişi değildir. Aynısı son döneminde olan insan fetüsleri, yeni doğanlar, belirli bir yaşa kadar çocuklar ve yaşları ne olursa olsun çeşitli sebeplerle Kant'ın kişilik tanımındaki zihinsel yetenekleri eksik olan tüm insan varlıkları için de geçerlidir. Böylece, tüm bu insanlar, kişilerin sahip olduğu ahlaki değerlerden mahrumdur. $\mathrm{Bu}$ bağlamda onların durumundaki insanlar direkt olarak saygılı davranış ödevine ve saygılı davranış hakkına sahip değillerdir. Regan, diğer canlılara davrandığımız gibi bu kişi olmayan insanlara yalnızca araç olarak davranacak olsaydık, Kant neden ve nasıl onlara herhangi bir yanlış eylemde bulunduğumuzu açıklayamazdı der (Regan 2003: 78).

Regan'ın temel eleştiri noktası Kant'ın kişi kavramı üzerinde odaklanmıştır. Kişilerin sahip olduğu yetilere sahip olmayan bu insanların da diğer canlılar gibi hakları olmadığı sonucuna götürür bizi, ki bu sonuç onların insan eylemlerinde saygılı davranışı hak etmediğini söyler. Regan, Kant etiğinin bu çıkarıma cevap vermede yetersiz kalacağını düşünür ve kendi fikrini ortaya atar. Ona göre, Kant etiğinde hak sahibi olan ve saygılı davranışı hak eden kişiler aynı zamanda yaşamın özneleridirler. Yaşamın özneleri olan bu kişiler içsel değere sahiptirler. Ancak Regan, bir yaşamın öznesi olan tüm canlıların içsel değeri olduğunu düşünür. Yaşamın özneleri olan bu canlılar artık birer araç olarak düşünülemezler. Çünkü onlar kendi yaşamlarının amaçlarını kendilerinde barındırırlar. Regan bir yaşamın öznesi olma düşüncesini şöyle açıklar:

Bir yaşamın öznesi olmak yalnızca dünyada olmak değildir, onlar dünyada olduklarının da farkında ve onların gözlerinin arkasındaki hayatta 'içeriden' meydana gelenlerin de farkındalardır. Böylelikle, bir yaşamın öznesi olanlar, yaşayan ve ölen bitkilerden farklı olarak canlı maddeden daha fazlasıdır; bir yaşamın öznesi olanlar yaşamlarının deneyim merkezidirler; hayatları başkaları tarafından değer verilip verilmediğinden bağımsız olarak kendileri için daha iyi veya daha kötü geçmiş olan bireylerdir. En azından memeliler ve kuşların durumunda, ulaştığımız sonuç basittir: esasen, bu hayvanlar, durumumuzdaki gerçeklikte olduğu gibi, bir yaşamın öznesidir (Regan 2003: 93).

Regan kitabında bugüne kadar ahlak felsefesinin üç kelime üzerine odaklandığını belirtir. Bunlar insanlar, hayvanlar ve kişilerdir. Buradaki üç kelimenin hiç biri diğer ikisi ile mükemmel denecek bir biçimde uyuşmazlar. Örneğin "tüm insanlar hayvandır" önermesi doğruyken, "tüm hayvanlar insandır" önermesi yanlıştır. Aynı şekilde az önce bahsettiğimiz sebeplerden dolayı bazı insanların kişi olmadıklarını, Kantçı anlamda ise hiçbir hayvanın kişi olmadığını söyleyebiliriz. Regan'a göre, bu kelimelerin örtüşememesinin temel sebebi insan ile hayvanların psikolojik olarak kesiştiği ortak bir alanı ifade eden dilsel bir yetersizliktir (Regan 2003: 93). Regan "bir yaşamın öznesi" ifadesinin dildeki bu boşluğu dolduracağını düşünür. Regan'a göre bu kavram, ortak bir statüde tüm canlıları tanımlamamıza izin verir:

İnsan kelimesi burada yetersiz kalır, çünkü bazı 'bir yaşamın özneleri' insan değildir. Hayvan kelimesi de aynı şekilde yetersizdir, bazı hayvanlar 'bir yaşamın 
özneleri’ değildir. Kişi kelimesi de yetersizdir zira bazı 'bir yaşamın özneleri' insan olsun olmasın kişi değildir. Ancak mevzubahis gerçekliliği karıştırmaya imkan yoktur, kelimenin tam anlamıyla milyarlarca insan ve hayvan varlı̆̆ tarafından paylaşılan bir gerçeği”" (Regan 2003: 93).

Regan'ın ortaya attığı bir yaşamın öznesi olma sadece insanlara değil, hayvanlara da içsel değer atfeder. Bir yaşamın öznesi olan hayvanların içsel değerinin olmadığını düşünürsek eğer, bu düşünüş tarzının insan-merkezci düşünüşte var olan türcülükten farkı olmayacağını belirtir Regan. Çünkü ona göre, "insan çıkarlarını ahlaki açıdan önemli saymak ve aynı çıkarları insan dışındaki varlıkların insan olmadığı için reddetmek ne kadar tür ayrımcılığıysa; bir hayatın öznesi olan insanlar için içsel değeri teyit edip insan olmayanlar için reddetmek de aynı şekilde tür ayrımcılığıdır” (Regan 2003: 94). Bu bağlamda kendi haklar görüşünün bu şekildeki tür ayrımcılıklarını ortadan kaldırdığını düşünür Regan. Ona göre bu haklar görüşü bir yaşamın öznesi olan insanların kim daha 'yüksek' kim daha 'üstün' ya da kim daha 'alçak' karşılaştırmasına göre sıralanmasını kategorik olarak reddettiği gibi; benzer sıralamayı hayvanlar ve insanlar kıyaslamasında da tutarlılık adına reddeder. Bir yaşamın öznesi olan tüm insanlar ahlaki açıdan önem değerlerinde (içsel değer) ne kadar az ya da çok bilirlerse bilsinler ve ne kadar yetenekli ya da yeteneksiz ve ne kadar zengin veya fakir olurlarsa olsunlar vs. eşittirler. Yalnızca tür ayrımcılığının son kalıntısı bizi bir yaşamın öznesi olan hayvanların vakasında aynı yargıya ulaşmaktan alıkoyar. Daha "yüksek” veya daha "üstün” değiliz, onlar da daha "alçak" veya daha "altta” değiller. Ahlaki önemimiz, içsel değerimiz açısından eşitiz (Regan 2003: 94).

\section{Çevre Felsefesinden Yöneltilen Eleştiriler}

Tarihsel süreçte diğer canlıların hakları mücadelesinde önemli adımlar atıldığını görmekteyiz. Bu bakımdan insan-merkezci görüşten yavaş yavaş sıyrılarak diğer canlıların da bu dünyada yaşama hakları olduğu gerçeği ile hesaplaşmak zorundayız. Hayvan hakları ve duyarlılık etiği bu gelişimde önemli derecede katkı sağlayan fikirler ve eleştiriler öne sürmüştür. Özellikle bir canlının ahlaki ilgiye layık olması için akıl sahibi olması gerekir savına yönelik eleştirileri, insan-merkezci etik anlayışına bağlı düşünürlerin de etiğin kapsamını genişletmelerine (burada yine insan tek başına değer sahibi olarak görülür, fakat diğer canlılara da ahlaki davranmak gerekir) vesile olmuştur. Nitekim bu eleştiri karşısında zihinsel engelli insanların, yeni doğan bebeklerin ya da bitkisel hayattaki hastaların durumlarını etik açıdan yorumlamada çok büyük sıkıntılar çekmekteydiler. Bu bakımdan Peter Singer ve Tom Regan'ın "bazı" hayvanları da etiğin kapsamına dahil etmeleri etik alanında önemli bir ilerleme olmuştur. Ancak bir önceki satırda özellikle vurgulanan "bazı" ifadesi de Singer ve Regan'ın fikirlerinin yetersiz olduğunu ve insan-merkezci bakış açısından tamamen kurtulamadığının işaretidir. Özellikle çevreci ve canl1-merkezci düşünürlerin bu konudaki eleştirileri bir hayli önemlidir.

Öncelikle duyarlılık etiğinin bir çevre etiği için yeterli olmadığına dair eleştiriler vardır. Bu yetersizliğin ise üç nedeni olduğunu belirtirler. İlki; geniş anlamda çevre etiği yok olma tehlikesi altındaki türleri, vahşi yaşamı ve ekosistemin bütünlüğünü korumaya çalışır, fakat duyarlılık etiğini savunan çevre etikçileri bu amaca uymazlar, onların 


\section{$248 \quad$ KOYQl 2018/30}

düşüncesi bütüncü bir bakış açısı değildir. İkinci olarak, bazı varsayımsal durumlarda (bunlardan en iyi bilineni "son adam" olarak adlandırılan durumdur) duyarlılık etiği çevre etiği ile çatışır. Burada duyarlılık etiği savunucuları ya farklı cevaplar verirler ya da bu durumu tamamen bir etik sorun olarak düşünmezler. Üçüncüsü, çevreciler direkt olarak türler ve ekosistem gibi bütüncül bir bakışla türleri korumayı çalıştığı için insanlar arasındaki çatışmalarla başa çıkmak için geliştirilen geleneksel etik teorinin kavramsal yapısı, çevrecilerin düşündüğü genel değer çerçevesinin yakalanması için uygun değildir (Varner 2001: 196).

Canl1-merkezci düşünür Holmes Rolston'a göre, çevreci etik düşünürler daha aşağı seviyede hayvanları, böcekleri, bitkileri, türleri, ekosistemi kapsamadığı için yalnızca duyarlı varlıkların veya belirli bir özellikteki hayvanların etik açıdan değerlendirebileceğine karşıdırlar. Hayvana dayalı bir etik, canlıların küçük bir kesimini oluşturan daha yüksek seviyedeki hayvanlara değinerek her şeyi yalnızca araçsal olarak değerlendirir. Çünkü besin zincirinde hayvanlar ve insanlar yaşam piramidinin en üstünde yer alırlar ve bu yüzden diğer canlılara ihtiyaç duyarlar. Çevre etikçileri buna katılmakta, ancak yine de bunun çok dar bir bakış açısı olduğunu düşünmektedirler. Biyolojik bakış açısından bu, insan dışında başka canlıları da değerlendirmesi açısından yine de iyi bir gelişmedir. Ancak daha derin bir yaşama saygı tüm yaşayan canlıları değerlendirir. Bu bakımdan hayvan hakları veya hayvan refahı etiği dünyayı biyosferik açıdan görme bakımından yaşamı tüm düzeylerinde değerlendirememektedir (Rolston 2012: 67-68).

Çevre felsefesinde önemli düşünürlerden biri olan Callicott da duyarlılık etiğinin bir çevre felsefesi için yeterli olmadığı kanaatindedir. Ona göre, Singer'ın faydacı görüşü ve Regan'ın haklar görüşü hayvan özgürlüğü ve hayvan refahı gibi terimlerle ifade edilse de onlar aslında duyarlılık etiği içerisinde değerlendirilmelidirler. Varner'in aktardığına göre, Callicott bu etiği, Aldo Leopold'un ortaya koyduğu ve kendisinin de destek verip geliştirdiği "yeryüzü etiği” ile kıyaslayarak eleştirir:

1."Yeryüzü etiği yerel çevreyi korumak için beyaz kuyruklu geyik (bu hayvanlar avcıları olmadığı takdirde aşırı üreme eğilimindedirler ve onların sayısının fazlalığı çevre bitkileri açısından oldukça tehlikelidir) gibi hayvanların avlanmasını yasaklamaz, ancak hayvan özgürlükçüleri böyle durumlarda dahi avlanmaya karşıdırlar.

2.Etik değerlendirmeleri açısından farklıdırlar. Onlar türü tehlikede olan hayvanlara ve avcılara kıyasla nadir türlere değer verirken, yeryüzü etiği büyük avcıları biyotik topluluğun kritik derecede önemli üyeleri olarak görür. Callicott'a göre hayvan özgürlükçüleri, bu hayvanları acımasız, vahşi ve uslanmaz birer katil olarak kınıyor olmalıdır. Bununla birlikte Callicott hümanist çobanların biyotik topluluğun istikrarı, bütünlüğü ve güzelliği için son derece önemli olan bitkiler üzerinde koyunların özgürce otlamalarına izin vereceğini ifade eder.

3.Hayvan özgürlükçüleri vejeteryanlığı savunurlar, fakat Callicott vejeteryanlığın her şeyi yiyen bir beslenmeden çok daha verimli olmasından dolayı evrensel vejeteryanlığın büyük ihtimal çevresel olarak felakete yol açacak derece insan nüfusunda artışa yol açacağını öne sürer.

4.Callicott tam anlamıyla evcilleştirilen hayvanlara özgü sonuçları da sıralar; ona göre bu hayvanlar ya hayatta kalamayacaklar; aniden yok olacaklar veya vahşi 
atlar gibi daha da vahşileşecekler ve çevrelerine zarar verecekler ya da sahipleri onları evde tutmaya ve beslemeye devam ederken onların kesilmesini durdurmak zorunda kalacaklardır ki böylece ekolojiye verdiğimiz zarar daha da artacaktır. Alternatif olarak bu hayvanların gelecek nesillerini yetiştirmeyi bırakma düşüncesi ise Callicott'a ironik görünür”' (Varner 2001:197).

\section{Sonuç}

Hayvan haklarına yönelik ortaya atılan bu görüşler, neden acı veya haz duymanın ya da bir yaşamın öznesi olmanın değerli olduğunu, diğer başka özelliklerin ise değersiz olduğunu açıklamada da yetersiz kalmıştır. İnsan-merkezci görüş insanların sahip olduğu bazı özelliklerden dolayı insanların değerli bir varlık olduğunu dolayısıyla da ahlaki ilgiye yalnızca onların mazhar olması gerektiğini düşünür. Nitekim insanmerkezciliğin en temel varsayımı, ahlakın ve değerin insana mahsus özellikler olduğu, yani ahlak ve değerin yalnızca insan var oldukça var olacağı ve yalnızca insanların ahlaki davranabileceği bu bakımdan da diğer canlılarda bu tür özellikler olmadığından onları etik açıdan değerlendirmenin gereksiz olduğudur. İnsan-merkezciliğin bu temel varsayımı hala geçerliliğini korumaktadır, yani diğer canlılar etik kapsamına dahil edilecekse bu varsayımla hesaplaşmak zorundadır. Ancak hayvan haklarına yönelik değindiğimiz görüşler bu varsayımı göz ardı etmişler ve yukarıda da bahsedildiği gibi asıl temellendirmelerini insanlarda var olan temel özelliklere sığınarak gerçekleştirmişlerdir. Bu bakımdan haz veya acıya sahip olmanın ya da bir yaşamın öznesi olmanın ahlaki ilgiye layık olma bakımından herhangi bir gerekçesi yoktur. Dolayısıyla neden bu özellik değil de şu özellik değerli sorusuna verebileceğimiz tek yanıt, bu özelliklerin insanlarda da bulunan en temel özelliklerle ortak olmasıdır.

Çevreci düşünürlerin eleştirileri de duyarlılık etiği veya hayvan refahı gibi hayvan haklarına yönelik düşüncelerin aslında insan-merkezcilik gibi dar bir bakışa sahip olduğunu göstermektedir. İnsan-merkezci etikte genellikle merkezde "akıl" varken burada "duyarlı olma" veya "öznel bir yaşama sahip olma" gibi özellikler vardır. Her iki bakış açısında da belirli niteliklere sahip olma temelinde bir etik görüş ortaya atılmakta ve bu niteliklere sahip olmayan canlılar etik kapsamı dışında bırakılmaktadır. Hayvanlara yönelik ortaya atılan bu fikirler aynı zamanda tüm hayvanları da kapsamamakta böylelikle hayvanlar arasında da bir değer hiyerarşisi kurmaktadır. Nitekim insan-merkezci düşüncenin en temel özelliği değer açısından insanın diğer canlılardan üstün olduğunun düşünülmesidir. Bu bakımdan hayvan haklarına yönelik ortaya atılan bu fikirler, insan-merkezci hiyerarşik yapıda değerli olan insanın yanına "bazı" hayvanları da eklemiş diğer canlıları ise yine alt tabakada düşünmüştür. Bunların yanı sıra hayvan haklarına yönelik bu düşünceler, akıl veya ahlaki davranabilme özelliklerinin yerine duyarlılık veya bir yaşamın öznesi olma özelliklerini geçirerek insan-merkezciliğin dilinden sıyrılamamıştır. Nitekim hayvanlara yönelik ortaya atılan etik görüşlere baktığımızda "insanlar gibi" acı çekebilen veya haz duyan ya da "insanlar gibi" bir yaşamın öznesi olabilen canlılar değerli görülmüştür. Bu bakımdan insanlarla ortak özelliklere sahip olma kriteri bu düşüncelerin temel motivasyonunu oluşturmaktadır. 


$250 \quad$ KOYQl $2018 / 30$

Eğer gerçekten yeni bir etik ${ }^{7}$ ortaya konacaksa insan-merkezci düşünce ile ciddi bir hesaplaşmaya girilmesi gerekmektedir. Bu bakımdan insan-merkezciliğin temel varsayımına cevap sunmakla birlikte, yeni bir değerler sistemi ortaya konulabilmelidir. Bunların yanı sıra yine insan-merkezciliğin sahip olduğu hiyerarşik ve ötekileştiren dili bir kenara bırakarak tüm canlıların değerli olduğu dolayısıyla da tüm canlıların ahlaki ilgiye layık olduğu ortaya konulmalıdır. Burada incelediğimiz hayvan haklarına yönelik görüşlerin bu özelliklere sahip olmadığ 1 görmekteyiz, ancak son yüzyıl içerisinde canl1merkezci düşünürlerin özellikle Paul Taylor ve Holmes Rolston'un çalışmaları yeni bir etiğin ortaya çıkabileceğinin sinyallerini vermiştir, ki bazılarınca bu görüşler yeni etik olarak düşünülmektedir. Burada detaylıca anlatma olanağı olmasa da kısaca baktığımızda her iki görüşün de değer sorunu ile ciddi bir şekilde hesaplaştığını ve yeni bir değerler sistemi ortaya koyduğunu söyleyebiliriz. Bu bakımdan sonuç olarak, insanmerkezci etiğin temel varsayımı olan değerin ve ahlaki davranabilmenin insana mahsus özellikler olması dolayısıyla yalnızca insanın değerli olması gerektiği savıyla hesaplaşan ve bu sava karşılık yeni bir sav ortaya atabilen canlı-merkezci etik kuramlar, yukarıda bahsettiğimiz hayvan haklarına yönelik etik kuramların çok ötesindedir. Dolayısıyla yeni bir etik için üzerinde durulması ve geliştirilmesi gereken hayvan haklarına yönelik temel kuramlar denilen görüşler değil, canlı-merkezci düşünürlerin ortaya attığ 1 görüşlerdir.

\section{KAYNAKÇA}

ARISTOTELES (1983). Politika, çev. Mete Tunçay, Ankara: Remzi Kitapevi.

AQUINAS, Saint Thomas (1920-1925). The 'Summa Theologica' of St. Thomas Aquinas, Translated by Fathers of the English Dominican Province, 22 vols., London: Burns Oats and Washbourne.

CALLICOTT, J Baird (2012). "Intrinsic and Instrumental Value" Encyclopedia of Applied Ethics, Ed. Ruth Chadwick, pp. 760-768, London: Elsevier Inc.

CALLICOT, J. Baird (1984). "Non-Anthropocentric Value Theory and Environmental Ethics”, American Philosophical Quarterly, 21(4)/2012: 299-309.

DERRIDA, Jacques (2002). "The Animal That Therefore I Am (More to Follow)”, trans. by David Wills, Critical Inquiry, 28(2)/2002: 369-418.

DESCARTES, Rene (1991). The Philosophical Writings of Descartes, ed. John Cottingham et al,. 3 vols. Cambridge: Cambridge University Press.

GORALNIK, L. Nelson; Michael P. (2012). “Anthropocentrism”, Encyclopedia of Applied Ethics, Ed. Ruth Chadwick, Callahan and Singer, pp. 145-155, Massachussetts: Academic Press.

7 Burada yeni etikle kast edilen klasik normatif etiğe, yani "geleneksel insan-merkezci etiğe karşı etiğin tüm canlıları veya çevreyi kapsayacak bir biçimde genişletilmesi, kısaca doğanın da etik topluluk içerisine dâhil edilmesi gerektiğidir" (Callicott 1984: 299). Bu bakımdan son zamanlarda etik, bazı düşünürlerce geleneksel etik ve yeni etik olarak ikiye ayrılmakta ve geleneksel etik görüşler eleştirilmektedir. 
KANT, Immanuel (1991). The Metaphysics of Moral, trans. by Mary Gregor, Cambridge: Cambridge University Press.

KANT, Immanuel (1997). Lectures on Ethics, trans. by Peter Heath, ed. Peter Heath \& J. B. Schneewind, Cambridge: Cambridge University Press.

KANT, Immanuel (2002). Ahlak Metafiziğinin Temellendirilmesi, çev. İoanna Kuçuradi, Ankara: TFK Yayınları.

MINTEER, Ben A. (2009). “Anthropocentrism”, Encyclopedia of Environmental Ethics and Philosophy, ed. J. Baird Callicott \& Robert Frodeman, New York: GALE.

REGAN, Tom (2003). Animal Rights, Human Wrongs, Oxford: Rowman \& Littlefield Publishers, Inc.

ROLSTON, Holmes (2012). A New Environmental Ethics: The Next Millennium for Life on Earth, New York: Routledge.

PLUHAR, E. (2012). “Animal Rights” Encyclopedia of Applied Ethics, ed: Ruth Chadwick, Callahan and Singer, Massachusetts: Academic Press.

SINGER, Peter (2011). Practical Ethics, New York: Cambridge University Press.

SINGER, Peter (2002). Animal Liberation, New York: Ecco Press.

STEINER, Gary (2005). Anthropocentrism and Its Discontents, Pittsburgh: University of Pittsburgh Press.

UEXKÜLL, Jakob Von (2010). A Foray Into The Worlds of Animals and Humans, Translated by Joseph D. O’neill, Minneapolis-London: The University of Minnesota Press.

VARNER, Gary (2001). “Sentientism”, A Companion to Environmental Philosophy, ed. by Dale Jamieson, pp. 192-203, Massachusetts: Blackwell Publishers. 
